\title{
吉益東洞の南部侯往診についての新史料
}

\author{
寺澤 捷年 $\mathrm{a}$ 板澤 正明b \\ a 千葉中央メデイカルセンター和漢診療科, 千葉， $=264-0017$ 千葉市若葉区加曽利町1835-1 \\ b ポランの内科クリニック，岩手， $\overline{\mathrm{T}} 020-0021$ 盛岡市中央通1-7-25 朝日生命盛岡中央通ビル $1 \mathrm{~F}$
}

\section{A New Historical Material on the Visitation to Lord Nambu by Dr Yoshimasu Todo}

\author{
Katsutoshi TERASAWA $^{\mathrm{a}}$ Masaaki ITAZAWA $^{\mathrm{b}}$ \\ a Department of Japanese-Oriental (Kampo) Medicine, Chiba Central Medical Center, 1835-1 Kasori-cho, Wakaba-ku, Chiba \\ 264-0017, Japan \\ b Polan Clinic, 1-7-25 Chuodori, Morioka-shi Iwate 020-0021, Japan
}

\begin{abstract}
According to the biography of Dr Todo Yoshimasu, he visited to Lord Nambu in 1752. However, this biography does not describe the detail of his therapeutic process. Recently we found out the historical materials, i.e. Zassho which is a diary written by a chief counselor of Morioka-Nambu feudal domain. This diary describes the detail of Dr Todo Yoshimasu's medical activity to the Lord Nambu. This report intends to introduce the description of this diary and discuss concrete activities of Dr Todo Yoshimas. This report is a new significant excavation since when publication Todo-zenshu in 1917.
\end{abstract}

Key words : Todo Yoshimasu, Lord Nambu, Zassho, diary of chief counselor

\section{要旨}

吉益東洞の伝記によると，彼は1752年に南部侯を往診している。しかしこの伝記には治療過程は記されていない。 最近筆者らは『雑書』という史料を見いだした。この書物は盛岡南部藩の家老によって記された日記である。この 日記には東洞の南部侯に対する治療の詳細が記されている。本稿はこの日記を紹介し，併せて吉益東洞の具体的な 行動について報告することを意図した。これは吉益東洞関連の史料として『東洞全集』出版（1917年）以来の意義 有る発掘である。

キーワード：吉益東洞, 南部侯, 雑書, 家老日記

\section{緒言}

『東洞全集』胡には, 吉益東洞の没後に息子達によっ て記された伝記『東洞先生行状』が収載されている。 この中に宝暦 2 (1752) 年に東洞が盛岡の南部候を 往診したことが記されている2)。

ところが，南部候の病状の詳細や用いた方剂につ いてはこれまで全く不明であった。筆者らは南部候 と東洞の関係がどの様なものであったかについて調 査を進める中で, 幸にも盛岡藩家老席日記『雑書』3) の中に，この疑問を解き明かす記述のあることを見 いだした。東洞の臨床治験については『建殊録』)等 に記されているが, この『雑書』の記述は東洞の臨 床の実際について㝝い知ることのできる貴重なもの と考えた。そこで, 本稿では『東洞先生行状』を参 考としつつ, 『雑書』に記されたあらたな知見につ
いて紹介し，検討を試みる。

1. 対象と方法

1)『東洞全集』に収められている『東洞先生行 状』の南部候往診の部分を検討の対象とした。

2 ）盛岡藩家老席日記『雑書』は, 家老席の書記 にあたる藩士が家老の政務日記として記したもので， 盛岡南部藩の代表的な公的記録である。家老職の責 務は藩の政務全般に及んでいたので，この日記には 家老席での協議・決定事項, 代官所など下部機関か らの報告, 家老職の日常的処理事項が主に記されて いる。原本は寛永から天保までの197年間の記録で ある。盛岡市教育委員会・盛岡市中央公民館が刊行 した『雑書』は毛筆で記された原文を解読し活字化 した刊本である。

本研究では, この活字本『雑書』の第22巻（寞延 
4 年一宝暦 2 年）を検討の対象とした。

2 . 結果

1) 『東洞先生行状』の記述

原文は漢文であるので，これを読み下した文章を 『吉益東洞の研究』占から引用する。

$\bigcirc$ 是の年（寛延 4 年）の春正月, 南部侯に病有 り。侍臣をして其の病状を審らかにせしめて, 処方 を先生に請う。先生の術を信じ, 侍医, 数輩をして, 先生に従学せしむ。此の時に方りて, 其の侍医, 孔 尹肅を召還して, 先生の処方を調進せしむ。其れ効 を得ず。明年二月に至りて, 既に危篤なり。先生を 其の国に召す。先生往きて診す。迺ち侯に謂いて曰 く「前剤応ぜざるに非ず。君侯の病劇しく, 未だ其 の験を得ざるなり。臣に他術なし。固より其の死生 を知らず」と。敢えて辞す。侯曰く「先生, 辞する こと勿れ。他医の能く治する所に非ざるなり。寊人,

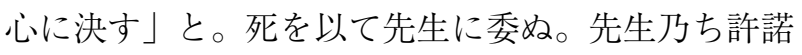
し, 益々前剂を進む。明日, 侍臣, 先生に謂いて日 く「寡君, 孔尹肅を黜く」と。先生曰く「何の故ぞ」 と。侍臣日く「昨, 先生進む所の薬は, 尹肅が献ず る所と同方にして, 寡君之を嘗め, 其の味大いに異 なれりと。故に其の学の粗なるを各むる」と。先生 曰く「侯，過てり，侯，過てり。方略を弁ぜざるの 過りなり。尹肃に何の罪あらん。夫れ方は伝うべく， 略は伝うべからず。尹肅用うる所の者は方にして, 我れ用うる所の者は略なり。君侯の病篤し。平剤の 能く応ずる所に非ざるなり。故に其の分量を陪す。 是れ味の異なる所以なり。請う, 試みに尹肅をして 其の分量を記せしめよ。吾も亦た以て之を証せん。 毫暒違うこと無し。是れ其の方なればなり。尹肅に 何の罪か有らん」と。侍臣, 諸れを侯に告ぐ。侯, 聴きて過を知る。即ち尹肅を赦す。是れに由りて益々 先生を信じ，議を政事に及ぶ。侯の病癒ゆること有 れば，必ず将に用いんとするなり。其の四月，侯の 病, 稍々退く。気体爽然として, 食始好進む。侯, 悦びに勝えず。先生を饗して, 左右に酒を賜う。公 族, 群臣, 初めて喜色有り。北奥の地, 四月もなお 大寒す。而れども一日熱すること盛夏の如きなり。 侯, 此の変気に遇い, 病勢復た加う。幾ど将に殆か らんと。逎ち, 訣して曰く「諸侯, 先生の薬を服す ること, 寡人尤も其れ先ならん。今, 良医の薬を服 して, 良医の手に斃るも, 頞人, 遺憾なし」と。言 絶え涙下りて逝きぬ。
この記述の要点を箇条書きすると：

1) 寛延 4 年の正月に南部侯が不調となり, 病状 を記した書状が届き処方を求められた。南部藩 侍医で東洞門下の穴沢尹肃が国元に帰り，東洞 から教示された処方を南部侯に差し上げたが無 効であった。（寛延 4 年10月に宝暦と改元）

2 ) 翌年（宝暦 2 年） 2 月に南部侯の病状が悪化。 盛岡への往診を依頼された。

3 ）東洞の治療により症状は改善。大いに感謝さ れた。

4) しかし, 気候変動のためか, 病状は再び悪化 し，亡くなった。

2 . 盛岡藩家老席日記『雑書』の記述

〔注記〕以下の引用文は家老職の者が記している が，主君を尊崇する意味で「前書有之通 屋形様」

「内々被 仰越候付」のように主君に関係する言葉 の前に一文字の空白を置いている。吉益東洞の東洞 は号で, 名は為則, 通称は周助である。ここには吉 益周助として記されている。周助に下線を付した。

宝暦 2 （1752）年 3 月 3 日（東洞往診の数日前の 記述)

屋形梯兼て御腰御居敷辺御痛被成御座。去年御下 向後六月中旬頃より御歩行御不自由之様二被遊御座 候付, 御側御用被 仰付置く候御医師穴沢立格御薬 被 召上, 御快方二被為 入, 七月中旬右御痛為御 保養, 䉆宿一二迴御入湯御相応被遊候付, 其後九月 中旬又候鶯宿へ御湯治三迴御入湯御相応被遊候処, 十月中旬より御動気被為出, 御息たわしく御足なと 少々御浮腫被遊御座候付, 立格被 仰付御薬附子六 物湯御用被遊, 尤宮杜桐庵御診被仰付, 段々御順 快二被成御座候処, 当正月十日頃より余寒御当被遊 候哉, 又々御不快二被成御座, 御瘦被為見, 御下通 御浮腫少々被成御座候付, 二月初頃嶋玄適御診被 仰付, 尤桐庵 - 立格儀も御診被仰付, 御薬八玄適 被 仰付, 三和散二御散薬山州桂散御用, 段々御薬 用被遊候処御同篇之内, 去儿朔日頃二至二分程御増 被遊候付, 朔日より御薬保脾湯玄適差上候付, 御腫 気少々御引被遊候様二被為入, 御腫気巡り御上通 八御増被遊候哉と相診候由, 御医師共申上之,

この記述の要点を記すと：

1）南部候は以前から腰・剧部の痛みがあったが, 昨年，江戸から国元に下向（4月）した後の 6 月中旬に痛みのために歩行困難となった。 
2 ）侍医の穴沢立格の薬で快方に向かった。

3） 7 月中旬に保養のため鶯宿で湯治。

4）10月中旬に動気が出現。呼吸も頻数となった。 下肢に浮腫。穴沢立格が附子六物湯を投与。そ の後は比較的順調に経過。

5 ）宝暦 2 年正月 10 日頃から痛みが再発。浮腫も 出現。

6 ） 2 月になり嶋玄適が主となり, 宮杜桐庵, 穴 沢立格が補佐。嶋玄適が三和散と山州桂散を投 与。わずかに有効。（本文には山州は山冠に州 の一文字であるが，伯州散に倣い，山城の国 · 山に州とした)。

7 ） 3 月 1 日頃に嶋玄適が保脾湯を投与。浮腫が 軽減。食事摂取量も増加した。

宝暦 2 年 3 月 16 日

前書有之通 屋形様御様躰御医師共相診, 御薬被 召上御同篇被成御座候内，兼て京都牢人医吉益周助 と申もの一御内々被 仰越候付, 先頃罷下候間被為 召御様射診被 仰付候処, 御腫気不少第一虚り御動 気御心下之動気強被遊御座候間, 御気遣二奉存候趣 申上候二付, 嶋玄適 - 宮杜桐庵へも対談被 仰付候 上, 去ル八日より周助二御薬被 仰付, 越婢架附湯 卜申御薬指上候処, 其後御小水御通利宜御動気も余 程御鎮り被遊候二付, 四五日も右之通打続御動気被 為止候得は御順快之趣二申上, 段々御薬差上候内, 去ル十一日より御心下之御動気強, 御脈等も御不出 来二候様奉診候趣申出儿, 然所同晚御雪隠入被為

入, 其節御胸間不宜由, 御意有之, 間もなく御吐逆 被遊, 御吐物八御食物八無之, 癡血之かたまり申様 成魚腸之ことき穢物壱ツ血交御吐被遊, 又候三度目 半時過薄血交を御吐被遊, 右三度之御吐逆以後御心 持殊之外宜御覚, 御胸之内透候様 思召候段 御意 有之, 右御吐物之儀周助へ御尋有之候処, 甚穢物二 て御座候, 中々一朝一夕之物二ては無之, 此物八随 分出申事宜御座候, 最初奉診付 御意被遊候八, 時々 御耳杯御鳴被遊候由, 右御答二も申上候通, 御血丑な と出申候八御耳之鳴相止可申旨申上候, ケ様之儀も 無之二八不然候得共, 鬼角内二有之候八 2 出申方宜 儀之由申上ル, 翌朝御うかい被遊候節, 又候御吐逆 有之, 昨夜三度目之御吐物之通二て其後八, 御吐物 相止, 御腫気八少々御引被遊候御様子二被為 入, 鬼角二三日打続右之通不被為 入候得八, 御順快之 方難申上奉存候, 御病八治シ候御様子御座候旨周助
申上, 其後去ル十二・十三日御容射御同篇之内, 御 気分八御宜被為 入, 御動気 ·御脈共差て御变り被 遊御儀不被成御座旨, 御医師共診之趣申出, 尤周助 儀十四日晚寄罷出相診候処, 右之通御容躰差て御変 不被遊候内, 虚り御動気八御鎮被成候得共, 御心下 之御動気強被為 入候付, 御薬方転し木防已湯卜申 御煎湯差上申旨, 一応相転し指上御様子次第又々前 方指上候様可仕旨申上候, 右之通御様躰別て御变も 不被遊, 御気分差て御変り不被為 入候得共, 御長 病之御儀故, 当御参勤之御時節前御全快被遊, 当月 御発駕可被遊御容躭二八不被成御座趣, 御医師共申 上候付, 右為御届御用人山本鄉助被, 仰付, 今日立 為御登, 左之通被 仰出,

兼て御持病之御脚膝痛, 去冬中より被為発, 此節 御浮腫差出御乗輿被遊候儀, 長途難御成御様躭二被 成御座候, 依之御参府御延引被成, 御快気次第御参 府可被遊旨（下略）

この記録の要点を箇条書きすると：

1) 宝暦 2 年 3 月 8 日診察開始。

2）前年からの膝痛・下肢痛が悪化。食欲不振で 臥床状態。下肢浮腫, 虚里 (心尖部) の動気, 心下の動気, 小便不利がある。越婢加术附湯を 投与。(本文の架は加术の誤り)

3 ）その結果, 尿量が増加。胸腹部の動悸も軽減。

4） 3 月11日。心下の動気が再度出現。脈も弱く なる。夕刻, 便所に行ったとき胸の不快感を自 覚。その後, 口から魚腸のような污い痰をひと かたまり吐いた。

5 ） 12 日午前 3 時頃, 薄く血液の混じった痰を吐 いた。この後, 気分が良くなり, 胸がすっきり した。

周助に尋ねると,「吐いた痰は非常に污く, 一朝一夕に胸の中に貯まった物ではない。この 様な体内の污物は出たほうが良い。初診時に耳 鳴りがすると言われたがこれも止まるでしょ う」との答えであった。

この朝, 洗面時に再び痰を吐いた。痰の性状 は午前 3 時頃のものと同じであった。その後, 痰を吐くことは無く, 下肢の浮腫も軽減した。

「これで食事が摂れるようになれば回復間違い ありません」と周助が言った。

$6 ） 13$ 日。気分も良く, 胸腹の動気も治まってお り，脈も正常になった。 
7 ）14日の晚。周助が再度の診察。全体的に良い 状態である。「虚里の動気は鎮まっているが, 心下の動気が強くなっているので木防已湯に転 方を試みたい」と周助が言った。病気は回復し, 気分も良い。

8 ）参勤交代で今月中に江戸に向け出発の予定で あるが，長期間の病気であったので，体力の回 復が十分ではない。出発は遅らせた方が良いと の侍医団の意見である。参勤を延引することを 幕府に願い出る。

『雑書』その後の記述 :

3 月20日。屋形様御様躰御同篇之内, 御動気も御 静被成候方二も御様子御宜被為 入候段, 御医師共 周助へ同夜御様躰相伺候趣申出, 尤周助相診候趣五 分々程二八御治シ被成候様二存上候由, 俄御えつき の御気味被成御座候付, 御薬方転シ小陥胸湯卜申御 煎湯差上候処, 打続御えつき被成御座候二付, 猶亦 御薬方相転, 获苓飲と申候煎湯差上以後, 御様射周 助罷出相診候処, 差て御変り不被遊御座候得共, 御 えつき強被成御座, 御膻中御動気強ク相成候得共, 御急変被為有御様躰二八無御座候由申聞儿, 右之御 薬御用被成, 御えつき御間遠二被成御座旨申出之。

3 月27日。屋形様御様躰, 去ル二十日周助御薬方 転上候以後, 御動気御鎮り御えつきも相止, 御膳等 御心能被 召上候得共御疲八被成御座, 差て御変り も被成御座候内, 昨二十六日より急二噯気二相成候 付, 猶亦御疲も被遊, 御昇之御気味も被成御座, 不 宜御様子被成御座, 今朝二至猶亦周助被為 召相診 候処, 御動気八昨日相診候よりは半過相減申候, 今 日八御胸一脇腹より御㾂差込御痛も有之候付, 御薬 方相転柴胡加桂湯卜申御煎湯差上, 御腫気も弥被為 引, 御病気は過半治シ申候様子二候共, 御疲被成御 座候付, 御食事等唯今迄之通二八不被 召上, 甚衰 御見得被遊候由, 依之周助辞退之義委細申出候付, 今晚より宮杜桐庵御薬可被召上旨被仰出, 清水 良庵診被 仰付, 桐庵へ相談仕, 御薬家方枳実湯差 上候処御痰少三静被為成, 御呼吸も少々御鎮被成 御座候得共, 御労レ殊之外被遊御座, 御胸御㾂も和 キ不申, 甚御差重被遊候容射被為 入旨, 御医師共 申出之。

屋形様御病気二付 公義入御医師御願被 仰上候。 3 月 28 日。屋形様御様躰以之外御勝不被遊旨桐庵 - 良庵申出, 尤御抔少々被 召上御湯被上候節, 急
御昇強御呼吸甚不宜候二付, 参熊丹差上候得共御届 不被遊, 御引炎等差上候得共御養生不被為 叶, 御 年四十五二て申ノ中刻御卒去被遊, 依之詰合高知 同子共 · 北九兵衛 $\cdot$. ・ 。

以上の要点を掲げると：

1）一時快復したかに見えた 6 日後の 3 月20日， えつき（吐物のない嘔逆）が出現。そこで小陥 胸湯に転方した。

2 ）無効であったので获苓飲に転方。えつきが軽 減した。

3 ）小康状態であったが 3 月26日から噯気が出現。 全身の衰弱が進行。

4） 3 月27日。容体が悪化。脇腹から胸に差し込 むようなつかえ感が起こった。そこで柴胡加桂 湯 (小柴胡湯加桂枝)に転方。これは有効であっ たが，食事摂取はできない状態になった。本文 の柴胡加桂湯は『東洞先生配剤録』を参照し小 柴胡湯加桂枝とした。

5 ）東洞（周助）は治療を辞退。

6 ）侍医の宮杜桐庵・清水良庵が治療に当たった。 枳実湯を用い，少しく有効であったが全身衰弱 が進んだ。

7 ) 重篤な病状であるので, 家老が幕府御典医の 急派を要請した。

8）3 月28日。薬を服用しようとしたところ突然 に卒倒し, 呼吸が途絶えがちになった。参熊丹 を服用させようとしたが飲み込めなかった。炎 も行ったが午後 4 時頃, 帰らぬ人となった。四 十五歳であった。

\section{3. 考察}

東洞が往診した盛岡南部藩主は 8 代藩主・南部利 視（としみ $1708-1752)^{6)}$ である。1725年に藩主に就 く。徳川吉宗の享保の改革に倣って藩の行財政改革 に取り組んだ名君で, 進取の気風に富んでいた。『吉 益家門人録』7よると, 南部藩侍医の東洞塾入門者 は第10番・穴沢尹肃, 11番・三浦道悦, 12番・福田 秀俊であり, 開塾早々の入門である。これは藩主の 意向を反映したものであったと『行状』は記してい る。なお，『行状』において穴沢尹肃は孔尹肃と儒 者として尊称されている。

東洞の年譜によると, 往診した宝暦 2 （1752）年 は東洞50歳。『類聚方』『方極』『薬徵』を脱稿して いた。往診については宝暦 2 年の 2 月であることは 
『行状』に記されているが, 詳細な月日は不明であっ た。このたびの新史料により，宝暦 2 年 3 月 8 日藩 主の診察開始が確定した。この数日前に東洞は盛岡 に到着していると考えて良い。京都から盛岡までの 旅程は約25日であるから，東洞が京都を出立したの は宝暦 2 年 2 月 8 日頃と推定される

藩主が両腿部痛と膝痛に悩んでいたことは前年に 知ったことで，これは病状を記し，処方を求めた書 状が寞延 4 年の春に東洞宛てに届いるからである。 この書状の仲介者は盛岡䕌侍医で東洞門下の穴沢尹 肃らと考えられる。

穴沢尹肃は返書を携えて盛岡に戻り, 治療を開始 した。恐らく具体的な方剤の指導を得ての帰藩であ る。

ところで，往診した東洞が具体的にどの様な方郕 を用いたのかはこれまで不詳であったが，このたび の史料によってそれが明らかになった。東洞の臨床 治験は『建殊録』と『東洞先生配剤録』9) から知るこ とができるが，ひとりの患者を前にして方剂を運用 してゆくありさまを『雑書』は活き活きと記してい る。

『奉答南部侯書』には下腿痛・膝痛の背後に宿疾 があること。この宿疾を取り除くには瞑眩を覚悟す べきこと。死生は天命であること。自らの親試実験 により得たものが確かであり, 陶弘景の説が妥当で 李時珍の説は臆説に過ぎないこと等が記されている。 この書には『千金方』や『外台秘要』も動員しての 論陣が張られているが，これは藩主のみならず守旧 派の侍医たちをも説得する狙いがあったものと推測 される。

そして，それまでの侍医団による治療が思わしい 成果を挙げていなかったこともあって，東洞が招か れた。

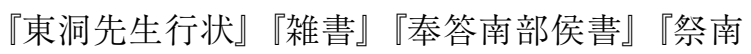
部源侯文』 ${ }^{10)}$ 織り交ぜると, 南部侯往診の顛末は 次のように纒められる。なお, 『雑書』につては上 記の引用文の他に寛延 4 年正月から宝暦 2 年の東洞 往診までの藩主の健康状態に関する断片的な記述も 組み入れた。

1) 寛延 4 年春に南部侯からの処方依頼書が届い

た（藩主は江戸より国元へ）。

2 ) 同年夏に『奉答南部侯書』として返信。

3 ) 南部藩侍医で東洞門下の穴沢尹肃が東洞の助
言を得て帰藩。

4 ）穴沢尹肃が治療に参加したが, 藩主の病状は 悪化。両下腿痛, 臂部痛, 膝痛に加え浮腫と食 欲不振が改善せず次第に重篤化。

5 ）往診の依頼を得て, 宝暦 2 年 2 月 8 日頃に京 都を出立。

6）3月 8 日に藩主の治療を開始。

7 ）越婢加术附湯・木防已湯により 3 月14日には 非常に良い状態になった。

この間, 魚腸のような血塊を吐き, 血液を混 えた喀痰が出ている。

8 ）江戸への参勤を論じるまでに病状は快復した。

9） 3 月20日。えつきが起こった。获苓飲で鎮ま る。

10） 3 月27日。重篤な状態に陥る。東洞は治療を 辞退。

11） 3 月28日。死亡。

なお，『行状』には帰途に東洞が江戸に止まり， 老中・堀田公から東洞の古医方と幕府御典医（望月 三英）の古医方との比較を行うことを将軍の命令と して受けたことが記されている。

$\bigcirc$ 先生, 北奥より東都に過る。堀田侯, 先生を その邸に召して謂いて曰く「内命あり。今, 汝が医 を試みよ」と。(『行状』) $)^{11)}$

この事案は 4 月に江戸に参勤しなければならな かった南部利視侯が参勤を延引した事情, 死亡に 至った状況などの釈明を幕閣の重役に対して行う事 を盛岡南部藩当局から要請され, 東洞が老中・堀田 侯に面会したことが発端になったものと推測してい る。参勤しないことは武家諸法度に違背するもので, 領国安堵に関わる重大事であったのである。

翌年，東洞は南部侯の一周忌に際して『祭南部源 侯文』を盛岡南部藩宛てに送り（宝暦 3 年 4 月）, 南部利視侯が東洞医論の良き理解者であったことに 心からの感謝の意を表している。

付記 Webサイトで吉益周助の名で検索したとこ 万, 東京大学医学図書館に『吉益周助事績関係書』が あることを見いだした。別書名は『吉益東洞南部家記 録』である。大正 6 （1916）年の書。柱に「盛岡南部 邸」の藍羁紙を用いており, 筆写者は恐らく盛岡南部 邸の資料整理に当たっていたと考元られる佐々木正郎 と山本茂昭である。青木正興からの質問に対する回答 
書で，20葉からなる仮綴冊子である。この冊子は本論 文で引用した『盛岡藩家老席日記・雑書』を筆写した ものである。

従って, 『雑書』を根拠とした本論文は東洞の盛岡 南部藩における事績研究という点では初めてのもので はない。しかし, 『吉益周助事績関係書』は学術書と して公表されたものではなく，私信であると考える。

謝辞 盛岡藩家老席日記・『雑書』における吉益周 助の記述については，もり扔か歴史文化館学芸員・熊 谷博史氏のご教示を得た。記して媣く感謝の意を表す る。

\section{利益相反（COI）に関して開示すべきものなし。}

\section{文献}

1 ) 芸備医学会 (呉秀三). 東洞全集. 復刻版, 思文閣, 京都 1970. 551-558.
2 ) 芸備医学会 (吳秀三). 東洞全集. 復刻版, 思文閣, 京都 1970. 554-555.

3 ）盛岡市教育委員会，盛岡中央公民館．盛岡藩家老席日 記·杂隹書 22 巻. 盛岡 2009. 262 .

4 ) 芸備医学会 (只秀三). 東洞全集. 復刻版, 思文閣, 京都 1970。473-500。

5 ) 寺澤捷年. 吉益東洞の研究. 岩波書店, 東京 2012 . 67-68.

6 ) 熊谷孝. 南部史要. 複刻版, 熊谷印刷出版部, 盛岡 1972. 131-152.

7 ) 町泉寿郎. 吉益家門人録. 日本医史学雑誌 2001 ; $47: 154-178$.

8 ）細井計，伊藤博幸，管野文夫，他. 岩手県の歴史. 山 川出版, 東京 1999. 219.

9 ）寺澤捷年. 吉益東洞の研究. 岩波書店, 東京 2012 . 189-190.

10）芸備医学会 (吳秀三). 東洞全集. 復刻版, 思文閣, 京都 1970. 540 .

11）寺澤捷年. 吉益東洞の研究. 岩波書店, 東京 2012 . 203. 